\title{
PRACE POGLĄDOWE
}

Piel. Zdr. Publ. 2016, 6, 2, 149-158

(c) Copyright by Wroclaw Medical University DOI: $10.17219 / \mathrm{pzp} / 61571$

ISSN 2082-9876

MaŁgorzata WŁochal ${ }^{1, A-D}$, Marian GrZYMisŁaWski ${ }^{2, A, E, F}$

\section{Nowe trendy leczenia żywieniowego w przypadku nieswoistych chorób zapalnych jelit}

\section{New Trends in the Dietary Treatment of Inflammatory Bowel Diseases}

\author{
${ }^{1}$ Klinika Chorób Wewnętrznych, Metabolicznych i Dietetyki, Uniwersytet Medyczny im. Karola Marcinkowskiego \\ w Poznaniu, Poznań \\ ${ }^{2}$ Klinika i Katedra Chorób Wewnętrznych, Metabolicznych i Dietetyki, Uniwersytet Medyczny \\ im. Karola Marcinkowskiego w Poznaniu, Poznań
}

A - koncepcja i projekt badania; B - gromadzenie i/lub zestawianie danych; C - analiza i interpretacja danych;

D - napisanie artykułu; E - krytyczne zrecenzowanie artykułu; F - zatwierdzenie ostatecznej wersji artykułu

\begin{abstract}
Streszczenie
Nieswoiste choroby zapalne jelit to grupa idiopatycznych schorzeń przewodu pokarmowego, takich jak: wrzodziejące zapalenie jelita grubego (colitis ulcerosa - CU), choroba Leśniowskiego-Crohna (Crohn's disease - CD) i makroskopowe zapalenie jelita grubego (colitis microscopica). Charakteryzują się przewlekle trwającym stanem zapalnym wywołanym niewłaściwą rekcją immunologiczną. Zarówno choroba Leśniowskiego-Crohna, jak i wrzodziejące zapalenie jelita grubego są ważnym i coraz większym problemem zdrowotnym w krajach rozwiniętych. Ścisła etiopatogeneza nieswoistych chorób zapalnych jelit jest dotychczas nieznana. Sugeruje się, że ich rozwój jest wynikiem wzajemnych interakcji między czynnikami genetycznymi, immunologicznymi oraz środowiskowymi. Do głównych objawów wrzodziejącego zapalenia jelita grubego i choroby Leśniowskiego-Crohna należą: biegunka, bóle brzucha, gorączka, uczucie ogólnego osłabienia oraz utrata łaknienia. Wymienione symptomy prowadzą do postępującej utraty masy ciała i rozwoju niedożywienia białkowo-energetycznego typu marasmus. Celem leczenia pacjentów cierpiących na nieswoiste choroby zapalne jelit jest poprawa jakości życia przez uzyskanie lub możliwie jak najdłuższe utrzymanie remisji choroby, zapobieganie rozwojowi jej powikłań oraz utrzymanie właściwego stanu odżywienia pacjenta. Oprócz leczenia farmakologicznego jednym z elementów terapii nieswoistych chorób zapalnych jelit jest leczenie żywieniowe. Standardy żywienia klinicznego dla wrzodziejącego zapalenia jelita grubego i choroby Leśniowskiego-Crohna sprecyzowane przez ESPEN w 2006 r. są aktualne do dziś. W dietetycznej terapii bezobjawowej postaci choroby dominuje klasyczny model żywienia opierający się na założeniach diety lekkostrawnej, niskotłuszczowej z ograniczeniem błonnika pokarmowego. Dodatkowo jest zalecana zwiększona podaż białka oraz niektórych witamin i składników mineralnych. W ostatnich latach zauważa się wśród naukowców, klinicystów i samych pacjentów zwiększenie zainteresowania także alternatywnymi metodami leczenia dietetycznego nieswoistych chorób zapalnych jelit. Popularne są diety restrykcyjne typu FODMAP, SCD oraz IBD-AID. Poszukuje się ponadto możliwości wykorzystania w diecie pacjentów cierpiących na nieswoiste choroby jelit nutraceutyków, czyli naturalnych składników żywności o pozytywnym wpływie na zdrowie człowieka (Piel. Zdr. Publ. 2016, 6, 2, 149-158).
\end{abstract}

Słowa kluczowe: nieswoiste choroby zapalne jelit, terapia żywieniowa, żywienie dojelitowe, dieta FODMAP, nutraceutyki.

\begin{abstract}
Inflammatory bowel disease (IBD) is a group of idiopathic disorders of the gastrointestinal tract. The major types of IBD are ulcerative colitis (CU), Crohn's disease (CD) and the macroscopic colitis. IBD is characterized by a chronic inflammatory condition caused by inappropriate immune response. Both $\mathrm{CD}$ and $\mathrm{CU}$ are a major and growing health problem in developed countries. The exact cause of IBD is unknown. It has been suggested that interactions between genetic, immunological and environmental factors are associated with the development of IBD. The main symptoms of UC and CD include diarrhea, abdominal pain, fever, general weakness and loss of appetite. These symptoms lead to progressive loss of body weight and marasmus-type protein-energy malnutrition. The aim of the
\end{abstract}


treatment of patients with IBD is prevention of undernutrition, improvement in quality of life and maintenance of remission. Next to pharmacological therapy, an important component of the treatment of patients with IBD is nutritional support. Proposed by ESPEN in 2006, the standards of clinical nutrition for CD and CU are currently recommended. Highly digestible, low-fat and low-fiber diet is usually used in asymptomatic IBD. In recent years, there is an increased interest in an alternative methods of nutritional therapy in IBD. Very popular are restrictive diets like: FODMAP, SCD and IBD-AID. In addition, researchers are studying the possibility of using nutraceuticals - natural food ingredients with a positive impact on human health (Piel. Zdr. Publ. 2016, 6, 2, 149-158).

Key words: inflammatory bowel diseases, diet therapy, enteral nutrition, FODMAP, nutraceuticals.

Nieswoiste choroby zapalne jelit (n.ch.z.j.) to grupa idiopatycznych schorzeń przewodu pokarmowego, takich jak: wrzodziejące zapalenie jelita grubego (colitis ulcerosa - CU), choroba Leśniowskiego-Crohna (Crohn's disease - CD) i makroskopowe zapalenie jelita grubego (colitis microscopica). Charakteryzują się przewlekle trwającym stanem zapalnym wywołanym niewłaściwą rekcją immunologiczną [1]. W przypadku CD zmiany zapalne przebiegają z zajęciem całej grubości ściany narządu, mają charakter ogniskowy oraz mogą dotyczyć każdego odcinka przewodu pokarmowego (najczęściej są umiejscowione w końcowej części jelita cienkiego oraz początkowej jelita grubego). Cechą charakterystyczną wrzodziejącego zapalenia jelita grubego jest natomiast wystąpienie stanu zapalnego wyłącznie na błonie śluzowej i podśluzowej jelita grubego. Zmiany w UC mają charakter ciągły. W przebiegu n.ch.z.j. rozróżnia się okresy remisji (wyciszenia) i zaostrzeń [1].

Zarówno CD, jak i CU są ważnym i coraz większym problemem zdrowotnym w krajach rozwiniętych, choć i w regionach, gdzie dotychczas współczynnik ich występowania był mały, notuje się zwiększenie zachorowalności na n.ch.z.j. Jak podaje Burisch et al. [2], zapadalność na n.ch.z.j. zwiększyła się w Europie w ciągu ostatnich 50 lat z 6,0 do 9,8 na 100 tys. osób na rok w przypadku UC i z 1,0 do 6,3 na 100 tys. osób na rok w przypadku CD. Obecnie największą częstość występowania n.ch.z.j. odnotowuje się na Wyspach Owczych. Dane epidemiologiczne dotyczące zapadalności na choroby zapalne jelit w Polsce nie są precyzyjne. Według informacji uzyskanych z 95 ośrodków w Krajowym Rejestrze Choroby Leśniowskiego-Crohna w Polsce jest zarejestrowanych 6155 chorych [3].

Ścisła etiopatogeneza n.ch.z.j. jest jak dotychczas nieznana. Sugeruje się, że ich rozwój jest wynikiem wzajemnych interakcji między czynnikami genetycznymi, immunologicznymi oraz środowiskowymi. Do wywołania choroby przyczyniają się: niewłaściwa dieta (duże spożycie tłuszczów, w tym tłuszczów nasyconych, nieprawidłowy stosunek kwasów tłuszczowych omega-3 i omega-6, nadmiar cukrów prostych i disacharydów oraz mięsa, niedobór błonnika pokarmowego), zakażenia bakteryjne (m.in. Mycobacterium paratuberculo- sis spp., Salmonella spp., Shigella spp.) i wirusowe (m.in. wirus odry, Cytomegalovirus), czynniki toksyczne (działanie chemicznych substancji dodatkowych, zwiększenie zanieczyszczenia środowiska, palenie tytoniu) oraz inne, np. działanie wolnych rodników tlenowych $[4,5]$. O udziale komponenty genetycznej w rozwoju n.ch.z.j. może świadczyć częstsze ich występowanie u osób spokrewnionych. Obecnie jest znanych wiele genów podatności na choroby zapalne jelit, m.in.: NOD2/ /CARD15, IL23R, ATG16L1, IRGM, DLG5. Zauważa się ponadto związek między n.ch.z.j. a allelami antygenów HLA umiejscowionymi na chromosomie 6 (HLA-DR2 dla CU; HLA-DR1 i DQ5 dla CD) [6]. Wśród czynników etiologicznych n.ch.z.j. wymienia się również niewłaściwy skład mikroflory jelitowej charakteryzujący się zwiększeniem liczby Bacteroides spp., Escherichia coli i Enterobacterium spp. w stosunku do Bifidobacterium i Lactobacillus spp. [7].

Do głównych objawów CU i CD należą: biegunka, bóle brzucha, gorączka, uczucie ogólnego osłabienia oraz utrata łaknienia. Wymienione symptomy prowadzą do postępującej utraty masy ciała i rozwoju niedożywienia białkowo-energetycznego typu marasmus. Częściej dotyka ono pacjentów cierpiących na CD niż CU i zwykle ogranicza się do fazy zaostrzenia choroby. Szacuje się, że problem niedożywienia dotyczy nawet $85 \%$ hospitalizowanych pacjentów cierpiących na n.ch.z.j. i wynika zarówno z patomechanizmu choroby (zmniejszone wchłanianie i zwiększone straty składników odżywczych drogą przewodu pokarmowego, zwiększenie tempa przemian energetycznych z powodu toczącego się stanu zapalnego), jak i ze strachu pacjenta przed spożywaniem posiłków [8]. U osób cierpiących na choroby zapalne jelit zauważa się (głównie w fazie zaostrzenia choroby) znaczące zmniejszenie zawartości beztłuszczowej masy ciała i zaburzenia funkcji tkanki mięśniowej [9]. Obserwuje się ponadto nieprawidłowości w rozkładzie tkanki tłuszczowej - zmniejszenie rezerw podskórnej tkanki tłuszczowej, a zwiększenie poziomu tłuszczu wisceralnego [10]. W badaniach biochemicznych u osób cierpiących na CD częste są takie nieprawidłowości, jak: niedokrwistość z niedoboru żelaza (ok. $60 \%$ chorych), hipoalbuminemia, niedobory wita- 
min (głównie $\mathrm{B}_{1}, \mathrm{~B}_{12}$, D i K) oraz pierwiastków śladowych $(\mathrm{Ca}, \mathrm{Mg}, \mathrm{K})[11,12]$. U pacjentów cierpiących na CU stwierdza się dodatkowo niedobór kwasu foliowego (jako skutek terapii sulfasalazyną) i cynku (10\% osób) [13, 14]. Niedożywienie zarówno ilościowe, jak i jakościowe wywiera negatywny wpływ na przebieg kliniczny choroby, odsetek powikłań pooperacyjnych oraz śmiertelność pacjentów cierpiących na n.ch.z.j. [15]. Celem leczenia osób zmagających się z tymi chorobami jest zatem nie tylko poprawa jakości życia przez uzyskanie i możliwie jak najdłuższe utrzymanie remisji choroby oraz zapobieganie rozwojowi jej powikłań, ale również utrzymanie właściwego stanu odżywienia pacjenta [16].

\section{Leczenie dietetyczne w przypadku nieswoistych chorób zapalnych jelit}

Oprócz leczenia farmakologicznego (5-ASA, kortykosteroidy, leki immunosupresyjne, antybiotyki) jednym $z$ elementów terapii pacjentów cierpiących na n.ch.z.j. jest leczenie żywieniowe [17]. Celem postępowania dietetycznego u tych pacjentów jest poprawa stanu odżywienia przez zapewnienie odpowiedniej podaży makro- i mikroelementów oraz wyeliminowanie produktów, które mogą nasilać objawy choroby. Niezbędne jest przeprowadzenie wnikliwej oceny stanu odżywienia pozwalającej rozpoznać pacjentów wymagających szybkiej interwencji żywieniowej. Standardy żywienia klinicznego dla CU i CD sprecyzowane przez ESPEN (The European Society for Clinical Nutrition and Metabolism) w 2006 r. przedstawia tabela 1 [18]. Zgodnie z nimi w celu poprawy stanu odżywienia u niedożywionych pacjentów cierpiących na n.ch.z.j. jest wskazane wdrożenie żywienia dojelitowego (enteral nutrition - EN) pod postacią suplementacji doustnej (oral nutritional supplements - ONS) lub żywienia przez zgłębnik (tube feeding - TF). EN jest bardzo skuteczne w przypadku leczenia ostrej fazy $\mathrm{CD}$ u dzieci oraz u pacjentów dorosłych, u których terapia kortykosteroidami nie jest skuteczna. Rekomendowane jest ponadto w żywieniu okołooperacyjnym oraz w celu utrzymania remisji choroby. Wykazano, że żywienie dojelitowe ogranicza stan zapalny oraz poprawia odżywienie pacjentów, zmniejszając tym samym ryzyko rozwoju powikłań niedożywienia. Co więcej, pozwala zminimalizować niepożądane skutki stosowania 5-ASA, steroidów, azatiopryny i 6-mekraptopuryny. W wyjątkowych sytuacjach, tj.: $\mathrm{w}$ przypadku wystąpienia przeciwwskazań do stosowania lub nietolerancji EN, niedrożności jelit lub przetok wydzielających dużo treści, a także zespołu krótkiego jelita należy zastosować krótkotrwałe żywienie pozajelitowe (parenteral nutrition - PN). ESPEN reguluje również kwestię suplementacji w n.ch.z.j., rekomendując jej stosowanie wyłącznie u tych pacjentów, u których istnieje ryzyko lub występują już niedobory składników odżywczych [18]. U chorych, u których stężenie hemoglobiny jest mniejsze niż $6,21 \mathrm{mmol} / \mathrm{l}(10 \mathrm{~g} / \mathrm{dl})$ należy doustnie lub dożylnie podać żelazo. Dzięki temu można uzyskać nawet $80 \%$ zwiększenie stężenia hemoglobiny i poprawę jakości życia pacjentów. Z uwagi na duże ryzyko rozwoju osteopenii spowodowanej zarówno niedoborami żywieniowymi (protein, Ca, witaminy D), działaniem cytokin prozapalnych, jak i steroidoterapią, u wszystkich pacjentów cierpiących na $\mathrm{CD}$ zaleca się zażywanie suplementów wapnia i witaminy $\mathrm{D}$ w dawkach odpowiednio: $1000 \mathrm{mg} /$ dobę i 800-1000 IE cholekalcyferolu/dobę. W przypadku osób, u których zaobserwowano znaczne niedobory, dawki te mogą się zwiększyć. W czasie leczenia sulfasalazyną należy natomiast rozważyć podaż witaminy $\mathrm{B}_{12}$ oraz kwasu foliowego [18].

Mimo że od sformułowania zaleceń leczenia żywieniowego dla n.ch.z.j. przez ESPEN mija już prawie 10 lat, są one nadal aktualne, co potwierdza przegląd 34 badań klinicznych z lat 1993-2014 dokonany przez Triantafillidis et al. [19]. Autorzy zwracają jednak uwagę na istnienie niezweryfikowanych wystarczająco kwestii, jak np.: wpływ kwasów tłuszczowych LCT diety elementarnej na efekt terapeutyczny w CD oraz skuteczność EN w przebiegu choroby Crohna u pacjentów leczonych środkami biologicznymi [20].

Również w przypadku bezobjawowej postaci choroby klasyczny model żywienia opierający się na założeniach diety lekkostrawnej, ubogotłuszczowej (do $40 \mathrm{~g}$ tłuszczu na dobę) z ograniczeniem błonnika pokarmowego, o zwiększonej zawartości białka (80-120 g/dobę) oraz odpowiedniej podaży witamin i składników mineralnych pozostaje niezmienny od kilku lat. Pacjentom zaleca się spożywanie 5-6 małych objętościowo, łatwostrawnych posiłków przygotowanych $\mathrm{z}$ uwzględnieniem odpowiednich technik obróbki kulinarnej. W zależności od nasilenia występujących objawów $\mathrm{z}$ diety eliminuje się: laktozę, fruktozę, sorbitol i włókna kolagenowe. Ważnym elementem podejmowanych działań dietetycznych jest także szczegółowa edukacja pacjentów cierpiących na n.ch.z.j. z zakresu zindywidualizowanego żywienia, kontrolowanie przestrzegania diety przez przegląd dzienniczków żywieniowych oraz 24-godzinne wywiady $\mathrm{z}$ losowo wybranych dni, a także uwrażliwienie pacjenta na konieczność modyfikacji zaleceń w zależności od przebiegu choroby. $\mathrm{W}$ okresie remi- 
Tabela 1. Leczenie żywieniowe w przypadku n.ch.z.j.

Table 1. Nutritional support in IBD

\begin{tabular}{|c|c|c|}
\hline & Choroba Leśniowskiego-Crohna & $\begin{array}{l}\text { Wrzodziejące zapalenie jelita } \\
\text { grubego }\end{array}$ \\
\hline $\begin{array}{l}\text { Cel leczenia } \\
\text { żywieniowego }\end{array}$ & $\begin{array}{l}\text { leczenie lub zapobieganie niedożywieniu } \\
\text { poprawa rozwoju i wzrostu u dorosłych i dzieci } \\
\text { poprawa jakości życia }\end{array}$ & $\begin{array}{l}\text { - wsparcie żywieniowe u cho- } \\
\text { rych niedożywionych lub } \\
\text { osób, u których stwierdzono } \\
\text { niewystarczajace spożycie }\end{array}$ \\
\hline Wskazania do EN & $\begin{array}{l}\text { aktywna faza choroby: } \\
\text { - jako samodzielna terapia u pacjentów dorosłych nieodpowiadają- } \\
\text { cych na leczenie kortykosteroidami, } \\
\text { - jako terapia skojarzona (EN + leki) u pacjentów niedożywionych } \\
\text { oraz mających zwężenie jelita, } \\
\text { - jako leczenie pierwszego rzutu u dzieci; } \\
\text { żywienie okołooperacyjne: } \\
\text { - u pacjentów, u których nastąpiła utrata masy ciała powyżej 10\% } \\
\text { w okresie } 3 \text {-6 miesięcy przed operacją, mających BMI < 18,5 kg/m² } \\
\text { lub stężenie albumin < } 30 \text { g/l; } \\
\text { uzyskanie i utrzymanie remisji choroby: } \\
\text { - w uporczywych zapaleniach jelit - ONS; } \\
\text { w remisji trwającej dłużej niż rok, jeżeli nie stwierdzono niedoborów } \\
\text { żywieniowych, nie ma udowodnionych korzyści stosowania EN }\end{array}$ & $\begin{array}{l}\text { aktywna faza choroby: } \\
\text { - brak udowodnionego po- } \\
\text { zytywnego wpływu EN i PN } \\
\text { - nierekomendowane; } \\
\text { utrzymanie remisji: } \\
\text { - nierekomendowane }\end{array}$ \\
\hline Stosowanie EN & \multicolumn{2}{|c|}{$\begin{array}{l}\text { podaż energii wynosząca } 25-35 \mathrm{kcal} / \mathrm{kg} \text { m.c./dobę wystarczająca na pokrycie zapotrzebowania organizmu; } \\
\text { TF lub ONS jako dodatek do normalnego żywienia: } \\
\text { - ONS (do } 600 \mathrm{kcal} / \text { dobę), } \\
\text { - TF (przy większym zapotrzebowaniu energetycznym) - standardowa dieta polimeryczna (wlew: } \\
\text { 20-120 ml/h) podawana przez sondę nosowo-żołądkową lub PEG; } \\
\text { w przypadku długotrwałego EN jest korzystne stosowanie wlewów nocnych, } \\
\text { EN we wlewie ciągłym wykazuje mniejszą częstość powikłań niż podaż w bolusie }\end{array}$} \\
\hline Formuła EN & $\begin{array}{l}\text { brak znaczącego wpływu wolnych aminokwasów oraz formuł na ba- } \\
\text { zie peptydów i całych protein - brak rekomendacji; } \\
\text { LCT, MCT, glutamina - brak istotnych korzyści; } \\
\text { formuły wzbogacane w TGF-b2 - pozytywny wpływ wymaga po- } \\
\text { twierdzenia w badaniach klinicznych }\end{array}$ & $\begin{array}{l}\text { wpływ kwasów omega-3, } \\
\text { glutaminy, maślanu na ak- } \\
\text { tywność choroby jest kontro- } \\
\text { wersyjny i niepotwierdzony } \\
\text { klinicznie }\end{array}$ \\
\hline Suplementacja & \multicolumn{2}{|c|}{ w fazie remisji wyłącznie u pacjentów, u których stwierdzono niedobory składników odżywczych } \\
\hline Wskazania do PN & \multicolumn{2}{|c|}{$\begin{array}{l}\text { wyłącznie u pacjentów: } \\
\text { - mających przeciwwskazania/potwierdzoną nietolerancję EN, } \\
\text { - u których nastąpiło zaostrzenie choroby, } \\
\text { - będących w okresie okołooperacyjnym (u osób cierpiących na niedrożność lub mających przetoki) } \\
\text { - z zespołem krótkiego jelita spowodowanym licznymi resekcjami }\end{array}$} \\
\hline
\end{tabular}

sji, jeśli pacjent nie odczuwa dolegliwości ze strony przewodu pokarmowego, należy zachęcać go do powrotu do diety racjonalnej, podążającej za rekomendacjami żywieniowymi dla populacji osób zdrowych. Zauważa się bowiem, że większość pacjentów z obawy przed nawrotem symptomów choroby rezygnuje $\mathrm{z}$ potraw lub produktów, które w fazach zaostrzenia n.ch.z.j. wywoływały dolegliwości poposiłkowe, a które w okresie remisji są zwykle dobrze tolerowane. Zrealizowane w $2014 \mathrm{r}$. badanie ankietowe potwierdziło, że pacjenci cierpiący na UC $(\mathrm{n}=98)$ zbyt często $\mathrm{w}$ stosunku do realnych wskazań eliminują ze swojego jadłospisu warzywa, owoce, produkty bogatobłonnikowe oraz nabiał [21]. Wskutek tego ich dieta staje się monotonna i grozi niedoborem energii, makroi mikroskładników. Lopes et al. [22] zwrócili uwagę na problem niedoborów wapnia $\mathrm{w}$ pożywie- niu dorosłych pacjentów cierpiących na n.ch.z.j. $(\mathrm{n}=65)$. Autorzy podają, że aż $64,7 \%$ respondentów znacznie ogranicza spożywanie produktów mlecznych, szczególnie w aktywnych postaciach CD i CU przebiegających z nasilonymi dolegliwościami żołądkowo-jelitowymi.

Wywiady przeprowadzone za pośrednictwem niemieckiej strony internetowej www.krankheitserfahrungen.de dotyczące 4 sekcji psychodietetycznych: "zarządzanie niepewnością", „jedzenie - między pragnieniem a awersją”, „bycie innym”, "profesjonaliści jako źródło dalszych niepewności" pokazały, że osoby cierpiące na n.ch.z.j. wyrażają stałą obawę wobec jedzenia oraz mają problem $\mathrm{z}$ wyborem właściwych dla siebie produktów spożywczych. Ankietowani pacjenci zwracali uwagę na trudności $\mathrm{z}$ zastosowaniem rekomendacji dietetycznych podczas formalnych spotkań to- 
warzyskich, jak np. wesela, wyjście do restauracji. Uznali, że dylematy dotyczące wyboru produktów w takich sytuacjach są dla nich na tyle stresujące, że aby ich unikać, wybierają izolację społeczną. Istnieje zatem potrzeba holistycznej opieki dietetycznej złożonej zarówno z edukacji żywieniowej, jak i psychodietetycznej pracy z pacjentem [23].

\section{Diety alternatywne i nowe trendy $w$ leczeniu żywieniowym pacjentów}

W ostatnich latach zauważa się wśród naukowców, klinicystów oraz samych pacjentów zwiększenie zainteresowania alternatywnymi metodami leczenia dietetycznego n.ch.z.j. Popularne są diety restrykcyjne typu FODMAP, SCD oraz IBD-AID. Poszukuje się ponadto możliwości wykorzystania w diecie pacjentów cierpiących na n.ch.z.j. nutraceutyków, czyli naturalnych składników żywności o pozytywnym wpływie na zdrowie człowieka.

\section{Alternatywne diety eliminacyjne}

Zaproponowana przez australijskich naukowców z Monash University dieta FODMAP (Fermentable Oligosaccharides, Disaccharides, Monosaccharides and Polyols), czyli dieta z ograniczeniem lub całkowitym wykluczeniem zdolnych do fermentacji, słabo wchłanialnych węglowodanów, takich laktoza, fruktoza, jak: fruktany, sorbitol i inne alkohole cukrowe, określanych mianem fermentujących oligo-, di-, monosacharydów i polioli cieszy się dużą popularnością wśród pacjentów borykających się zespołem jelita drażliwego. Istnieją przeglądy badań potwierdzające hipotezę, że dieta $\mathrm{z}$ małą zawartością zdolnych do fermentacji, słabo wchłanialnych węglowodanów w 50\% przypadków prowadzi do ustąpienia objawów zespołu jelita drażliwego (z.j.d.), ale dowody na słuszność stosowania FODMAP w leczeniu dietetycznym pacjentów mających zaburzenia czynnościowe są niewystarczające i wątpliwe [24-26]. Z uwagi na podobieństwo symptomów z.j.d. i n. ch.z.j., takich jak: wzdęcia, poposiłkowe bóle brzucha czy biegunki, wiele doniesień z ostatnich lat koncentruje się na wykazaniu słuszności stosowania diety FODMAP również wśród pacjentów cierpiących na chorobę zapalną jelit. Australijskie badanie przeprowadzone w grupie 52 pacjentów chorujących na CD i CU pokazało, że dieta FODMAP u prawie połowy badanych spowodowała zmniejszenie nasilenia 5 spośród 10 ocenianych objawów choroby, takich jak m.in.: ból brzucha, wzdęcia i biegunka [26]. Metaanaliza danych pochodzących z 22 badań dotyczących wpływu FODMAP na objawy z.j.d. i n.ch.z.j. wskazuje na jej skuteczność w zmniejszaniu nasilenia symptomów choroby i poprawie jakości życia pacjentów [27]. Sugeruje się, że połączenie strategii FODMAP $\mathrm{z}$ tradycyjnymi zaleceniami dietetycznymi może być skutecznym sposobem na redukcję objawów z.j.d. [28]. Potrzebne są jednak dalsze badania na większej populacji pacjentów oceniające długoterminowe skutki stosowania diety o małej zawartości FODMAP.

Specjalna dieta węglowodanowa, czyli dieta SCD opisana przez Sydney Valentine Haas i Elaine Gottschall w połowie XX w. dla pacjentów cierpiących na celiakię, szybko została spopularyzowana wśród pacjentów, u których rozpoznano także inne choroby jelit. Zgodnie z jej założeniami pacjenci powinni rezygnować ze spożywania polisacharydów (w tym także ze skrobi) i disacharydów. Dozwolona jest natomiast podaż węglowodanów o prostej strukturze cząsteczki (monosacharydów) zawartych w owocach, niektórych warzywach i miodzie, gdyż są one łatwo wchłanianie i trawione w przewodzie pokarmowym. Ważnym elementem diety SCD są wolne od laktozy, probiotyczne produkty mleczne fermentowane. Istnieją pojedyncze doniesienia o pozytywnym wpływie SCD na przebieg n.ch.z.j. u dzieci i dorosłych [29]. Jedno $\mathrm{z}$ nich opisuje przypadek 73-letniej pacjentki, u której nastąpiło zaostrzenie CU, a po zastosowaniu diety SCD w okresie 3-6 miesięcy odnotowano zmniejszenie symptomów choroby, a w ciągu roku całkowite ustanie bólu brzucha i biegunek [30].

Aby pomóc pacjentom opornym na leczenie farmakologiczne lub tym, u których leczenie to nie jest wystarczająco skuteczne, opracowano tzw. dietę przeciwzapalną (IBD-AID). Założenia IBD-AID opierają się na podłożu diety SCD i polegają na:

- ograniczeniu/wykluczeniu niektórych węglowodanów (laktozy, cukrów rafinowanych i przetworzonych, węglowodanów złożonych), a spożywaniu węglowodanów prostych (monosacharydów),

- podaży pre- i probiotyków (np. rozpuszczalny błonnik, mleczne produkty fermentowane),

- modyfikacji składu kwasów tłuszczowych w pożywieniu,

- pokryciu zapotrzebowania na składniki mineralne i witaminowe oraz obserwacji organizmu w celu rozpoznania ewentualnych nietolerancji pokarmowych,

- zmianie tekstury żywności (np.: blendowanie, gotowanie) $\mathrm{w}$ celu poprawy wchłaniania składników odżywczych i minimalizacji drażniącego działania błonnika [31].

Elementami odróżniającymi IBD-AID od diety SCD jest brak zakazu spożywania glutenu, zainte- 
resowanie źródłem tłuszczu w diecie (zmniejszenie całkowitej zawartości tłuszczów, eliminacja tłuszczów trans, zwiększenie spożycia kwasów tłuszczowych omega-3) oraz możliwość wykorzystania owsa, który zapewnia substrat fermentacyjny dla probiotyków. Istnieją nieliczne badania kliniczne dotyczące skuteczności diety IBD-AID u pacjentów borykających się z n.ch.z.j. Olendzki et al. [31] dokonali obserwacji 40 pacjentów chorujących na $\mathrm{CD}$ lub CU, którym zalecili stosowanie diety IBD-AID przez 4 tygodnie. Już we wstępnej fazie $z$ interwencji żywieniowej zrezygnowało 33\% pacjentów. $\mathrm{W}$ pozostałej grupie osób aż 24 pacjentów dobrze zareagowało na dietę. Pogłębiona analiza 11 wybranych chorych wykazała, że u wszystkich $\mathrm{z}$ nich po zakończeniu dietoterapii IBD-AID było możliwe zmniejszenie dawki wcześniej przyjmowanego leku. Wszyscy pacjenci zauważyli ponadto mniejsze nasilenie dolegliwości [31]. Dokładny mechanizm działania IBD-AID jako alternatywy w leczeniu skojarzonym n.ch.z.j. nie jest wyjaśniony. Opiera się na hipotezie, że węglowodany złożone słabo trawione $\mathrm{w}$ przewodzie pokarmowym (nawet te o właściwościach biotycznych) mogą prowadzić do przerostu bakteryjnego i zwiększonej przepuszczalności jelit, a produkty fermentacji niestrawionych węglowodanów (metan, $\mathrm{CO}_{2}$, wodór, kwas mlekowy i octowy) są drażniące dla przewodu pokarmowego. IBD-AID bazuje na strategii dążącej do zmiany składu mikroflory jelitowej [31]. Mimo że wstępne doniesienia wydają się obiecujące, wymagają rzetelnej oceny w dalszych badaniach klinicznych. Trzeba mieć ponadto na uwadze to, że model diety IBD-AID jest bardzo restrykcyjny i aby był właściwie stosowany, wymaga od pacjenta zdeterminowania oraz nieprzeciętnej świadomości żywieniowej.

\section{Nutraceutyki we wspomagającym leczeniu n.ch.z.j.}

Polifenole obecne w warzywach i owocach mają udokumentowane właściwości przeciwutleniające. Istnieją dowody na korzystny wpływ polifenoli (antocyjanów, kurkumy, EGCG, naringeniny, kwasu elagowego, kwercetyny, resweratrolu, polifenoli jabłek, borówki, granatu) na tłumienie reakcji zapalnej w n.ch.z.j. przez regulację stężenia cytokin oraz enzymów antyoksydacyjnych. Boussenna et al. [32] wykazali protekcyjny wpływ 21-dniowej podaży bogatego w polifenole ekstraktu $\mathrm{z}$ winogron na indukowane przez DSS (dextran sulfate sodium) wrzodziejące zapalenie jelita grubego u myszy. Ekstrakt moduluje aktywność mieloperoksydazy i enzymów przeciwutleniających. Hamuje ponadto wzrost cytokin prozapalnych i reguluje ekspresję genów związanych z rozwojem CU (ICAM-1 i MMP-9). Podobnie ochronny wpływ przed zmianami obserwowanymi w przebiegu $\mathrm{CU}$ wykazują polifenole otrąb sorga [33]. Istnieje jednak potrzeba badań przedklinicznych i klinicznych niezbędnych do opisania bezpieczeństwa, biodostępności i skuteczności biologicznej polifenoli u pacjentów cierpiących na zapalne choroby jelit [34].

Brazylijski żeń-szeń - Pfaffia paniculata (suma) to adaprogenna roślina lecznicza stosowana w brazylijskiej medycynie ludowej, która wykazuje działanie przeciwzapalne. Costa et al. [35] dowiedli na modelu eksperymentalnym skuteczności podaży $P$. paniculata $\mathrm{w}$ redukcji stresu oksydacyjnego, stężenia cytokin prozapalnych (IL-1, IFN- $\gamma$, TNF- $\alpha$ i IL-6), CRP oraz aktywności mieloperoksydazy u szczurów, u których wywołano zapalenie okrężnicy kwasem trinitrobenzenosulfonowym (TNBS). Pfaffia paniculata wykazywał ponadto aktywność immunomodulacyjną.

W badaniach wykazano także pozytywny wpływ apigeniny (bioflawonoidu obecnego w selerze, karczochu i meksykańskiej odmianie oregano) na złagodzenie morfologicznych i biochemicznych markerów stanu zapalnego w CU. U zwierząt $\mathrm{w}$ stanie przedklinicznej postaci wrzodziejącego zapalenia jelita grubego podaż apigeniny K zmniejszyła powierzchnię stanu zapalnego, doprowadziła do istotnego zmniejszenia aktywności mieloperoksydazy (MPO), fosfatazy alkalicznej oraz normalizacji ekspresji TNF- $\alpha$, TGF- $\beta$ i IL-6 [36].

Wiele uwagi poświęcono możliwości stosowania probiotyków we wspomagającym leczeniu n.ch.z.j. Wykazano, że w przypadku CD działanie to nie przynosi oczekiwanych rezultatów. W CU odnotowuje się natomiast stosunkowo niewielką (15\% w stosunku do grupy placebo) liczbę osób, u których wystąpiła remisja choroby po zastosowaniu probiotyków [37]. Badanie Kruis et al. [38] wykazało ponadto podobną do mesalazyny skuteczność szczepu Escherichia coli w utrzymywaniu remisji CU. Mimo to $\mathrm{w}$ świetle obecnej wiedzy nie można jednoznacznie stwierdzić, czy terapia probiotykami w przypadku n.ch.z.j. powinna być rekomendowana.

Fruktany, czyli małocząsteczkowe polimery D-fruktozy, np. inulina, wykazują działanie prebiotyczne. Ich podaż u osób cierpiących na n.ch.z.j. bywa kontrowersyjna, bowiem fruktany mogą mieć dwojaki wpływ na przebieg choroby. Z jednej strony przez stymulację mikroflory jelitowej mogą działać protekcyjnie przeciw rozwojowi CD, ale $\mathrm{z}$ drugiej nasilają czynnościowe objawy choroby. Badanie Andersona et al. [39], którego celem była ocena wpływu podaży fruktanów i oligofruktozy u pacjentów cierpiących na chorobę Crohna wykazała, że pacjenci, u których rozpoznano aktywną postać $\mathrm{CD}(\mathrm{n}=98)$ zwyczajowo spożywają 
mniejsze ilości fruktanów i oligofruktozy (mediana: 2,9 g/dobę i 2,8 g/dobę) niż osoby, u których rozpoznano nieaktywną postać choroby $(\mathrm{n}=99)$ (3,6 g/dobę i 3,8 g/dobę) lub zdrowe $(\mathrm{n}=106)$ (3,9 g/dobę i 3,8 g/dobę). Opisano ponadto negatywną korelację między spożywaniem fruktanów a stwierdzanymi dolegliwościami $(\mathrm{p}=-0,157)$ i samopoczuciem pacjentów ( $\mathrm{p}=-0,154)$ ocenianym na podstawie kwestionariusza (HBI well-being score). Podobne wnioski dotyczące samopoczucia i oceny symptomów choroby dotyczyły również oligofruktozy (kolejno: $\mathrm{p}=-0,156 ; \mathrm{p}=-0,164$ ).

Kwas masłowy (butanowy; $\mathrm{C}_{4} \mathrm{H}_{8} \mathrm{O}_{2}$ ) to organiczny związek chemiczny z grupy kwasów karboksylowych, należący do grupy krótkołańcuchowych kwasów tłuszczowych (short chain fatty acids - SCFA) naturalnie występujących w jelicie grubym człowieka. Powstaje na skutek fermentacji bakteryjnej nierozpuszczalnego włókna pokarmowego i skrobi opornej w obrębie okrężnicy i ma udowodnione pozytywne działanie na przewód pokarmowy [40]. Maślan stanowi źródło energii dla kolonocytów, poprawia szczelność nabłonka, zmniejsza ryzyko nowotworzenia oraz wykazuje właściwości przeciwzapalne [41]. Zawartość endogennego kwasu masłowego jest zależna od stosowanej diety - zwiększa ją zarówno podaż produktów bogatych w maślan (mleka, serwatki, mlecznych produktów fermentowanych), jak i duże spożycie błonnika pokarmowego oraz pro- i prebiotyków [42]. Z uwagi na zróżnicowaną kondycję funkcjonalną jelit i występowanie dolegliwości po produktach zawierających zwiększoną ilość włókna roślinnego nie u wszystkich pacjentów można zrealizować model żywienia stymulujący endogenne wydzielanie kwasu masłowego. W takim przypadku stosuje się suplementację preparatami maślanu sodu. Udowodniono, że podaż maślanu sodu hamuje aktywność mediatorów zapalnych (redukcja sekrecji IL-8), wykazuje pozytywne działanie czynnościowe (reguluje procesy wchłaniania zwrotnego wody i sodu w jelicie, przywraca właściwą perystaltykę jelit i ich mikroflorę) oraz przez redukcję nadwrażliwości receptorów jelitowych prowadzi do zmniejszenia ciśnienia śródjelitowego [40]. Z uwagi na duże bezpieczeństwo oraz brak istotnych działań niepożądanych terapia maślanem sodu może być stosowana we wszystkich grupach wiekowych [41].

Wielonienasycone kwasy tłuszczowe z rodziny omega-3 mają udokumentowane działanie przeciwzapalne i immunomodulacyjne. Ich pozytywny udział w hamowaniu reakcji zapalnej w przebiegu n.ch.z.j. opisuje wiele badań $[43,44]$. Obecnie kilka prac koncentruje się na określeniu stosunku kwasów tłuszczowych omega-6/omega-3, który byłby najkorzystniejszy w dietoterapii CD i CU. Tyagi et al. [45] zaobserwowali na modelu doświadczalnym, że zmniejszenie proporcji między podawanymi kwasami omega-6/omega-3 skutkuje lepszą ochroną przed rozwojem zapalenia jelita grubego. Jak podaje Huang et al. [46], najlepsze efekty przeciwzapalne przynosi podaż kwasów tłuszczowych omega-6/omega-3 w stosunku 2:1.

Należące do żywności funkcjonalnej $\beta$-glukany owsa również wykazują działanie protekcyjne przeciw rozwojowi stanu zapalnego w obrębie jelita grubego. Badanie Liu et al. [47] wykazało, że u myszy, u których wywoływano $\mathrm{CU}$ za pomocą DDS (dextran sulfate sodium) podaż $\beta$-glukanów $\mathrm{w}$ dawce $500 \mathrm{mg} / \mathrm{kg}$ m.c./dobę zmniejszyła nasilenie klinicznych objawów choroby. W porównaniu z grupą kontrolną zwierzęta karmione paszą $\mathrm{z}$ dodatkiem $\beta$-glukanów miały mniejszą utratę masy ciała, rzadziej występowały u nich biegunki, a w badaniach histopatologicznych mniej nasilone zapalenie okrężnicy. Udowodniono ponadto, że suplementacja $\beta$-glukanami zmniejsza aktywność mieloperoksydazy (MPO), tlenku azotu (NO) i dialdehydu malonowego (MDA) w surowicy krwi oraz hamuje ekspresję mRNA i białek prozapalnych, takich jak TNF- $\alpha$, IL-1, IL-6 i NOS.

W ostatnich latach zauważa się także pozytywny wpływ bioaktywnych peptydów obecnych w żywności na hamowanie procesu zapalnego, modulowanie składu i translokacji mikroflory jelitowej oraz przepuszczalność błony śluzowej jelit. Wśród zbadanych metodami in vitro i in vivo peptydów nutraceutycznych o możliwości zastosowania w odniesieniu do n.ch.z.j. wymienia się najczęściej: glikomakropeptyd, $\beta$-kazeinę, otrzymywany z kazeiny peptyd QEPVL (Gln-Glu-Pro-Val-Leu), peptydy kolostrum, hydrolizaty $\mathrm{z}$ białek mięsa rekina, żółtek jaja, nasion grochu, amarantusa, soi, migdałów, mleka jaka zwyczajnego i inne [48]. Glikomakropeptyd (GMP), czyli peptyd pochodzący z א-kazeiny, ma właściwości przeciwbakteryjne i przeciwzakrzepowe. GMP wyróżnia wyjątkowy skład aminokwasowy charakteryzujący się dużą zawartością treoniny i izoleucyny oraz brakiem aminokwasów aromatycznych, takich jak fenyloalanina, tyrozyna i tryptofan, dlatego jest stosowany jako dobre źródło białka w diecie osób chorych na fenyloketonurię [49]. Sugeruje się ponadto, że pokarmy funkcjonalne zawierające GMP mogą być korzystne dla osób cierpiących na n.ch.z.j. Sawin et al. [50] wykazali na modelu zwierzęcym, że u myszy otrzymujących izoenergetyczne posiłki z suplementami GMP przez 8 tygodni zauważa się zmniejszenie wykładników stanu zapalnego - niższy poziom IFN- $\gamma$, TNF- $\alpha$, IL-1 i IL- 2 w porównaniu ze zwierzętami otrzymującymi aminokwasy lub kazeinę. GMP wpłynęło również pozytywnie na skład mikroflory jelitowej oraz zwiększenie stę- 
żenia krótkołańcuchowych kwasów tłuszczowych, octanu, propionianu i maślanu. Chociaż dostępne informacje wskazują na możliwości zastosowania bioaktywnych peptydów pochodzących z żywności w modyfikacji przebiegu n.ch.z.j., są konieczne dalsze badania pozwalające na lepsze zrozumienie ich mechanizmu działania i skuteczności.

\section{Podsumowanie}

Nieswoiste choroby zapalne jelit to stale zwiększający się problem zdrowotny w krajach rozwiniętych. Oprócz leczenia farmakologicznego jednym z elementów terapii n.ch.z.j. jest postępowanie dietetyczne mające na celu przeciwdziałanie rozwojowi niedożywienia, uzyskanie lub utrzymanie remisji choroby oraz poprawę jakości życia chorych. Wiele zagadnień związanych $\mathrm{z}$ interwen- cją żywieniową zarówno w ostrej, jak i asymptomatycznej postaci CD i CU jest dobrze zbadanych i skutecznych. Mimo to badacze poszukują nowych, alternatywnych metod leczenia żywieniowego pacjentów cierpiących na choroby zapalne jelit. Ważny element postępowania dietetycznego w n.ch.z.j. stanowi właściwa edukacja pacjenta $\mathrm{z}$ zakresu rekomendowanej, zindywidualizowanej diety, kontrolowanie jej przestrzegania oraz uwrażliwienie pacjenta na konieczność modyfikacji zaleceń w zależności od przebiegu choroby. Dużą popularnością cieszą się w ostatnich latach restrykcyjne diety typu: FODMAP, SCD, IBD-AID oraz związki o właściwościach nutraceutycznych, np.: polifenole, pro- i prebiotyki, $\beta$-glukany, wielonienasycone kwasy tłuszczowe omega- 3 czy bioaktywne peptydy. Ich pozytywny wpływ na przebieg choroby nie jest w pełni poznany i wymaga dalszych obserwacji.

\section{Piśmiennictwo}

[1] Zawadzka P.: Nieswoiste zapalenia jelit - wczoraj i dziś. Now. Lek. 2006, 75(5), 480-485.

[2] Burisch J., Munkholm P.: The epidemiology of inflammatory bowel disease. Scand. J. Gastroenterol. 2015, 50(8), 942-951.

[3] www.chorobacrohna.pl (data dostępu: 29.09.2015).

[4] Hou J.K., Abraham B., El-Serag H.: Dietary intake and risk of developing inflammatory bowel disease: a systematic review of the literature. Am. J. Gastroenterol. 2011, 106(4), 563-573.

[5] Ashwin N., Ananthakrishnan A.N.: Epidemiology and risk factors for IBD. Nat. Rev. Gastro. Hepat. 2015, 12, 205-217.

[6] Yamamoto-Furusho J.K.: Genetic factor associated with the development of inflammatory bowel disease. World J. Gastroenterol. 2007, 13, 5594-5597.

[7] Szajewska H., Horvath A., Dziechciarz P.: Probiotyki, prebiotyki i synbiotyki w leczeniu nieswoistych zapaleń jelit - przegląd systematyczny. Pediatr. Współcz. Gastroenterol. Hepatol. Żyw. Dziecka 2007, 9(4), 266-275.

[8] Vagianos K., Bector S., McConnell J., Bernstein C.N.: Nutrition assessment of patients withinflammatory bowel disease. J. Parenter. Enteral. Nutr. 2007, 31, 311-319.

[9] Jahnsen J., Falch J.A., Mowinckel P., Aadland E.: Body composition in patients with inflammatory bowel disease: a population-based study. Am. J. Gastroenterol. 2003, 98, 1556-1562.

[10] Peyrin-Biroulet L., Loftus E.V. Jr, Colombel J.F., Sandborn W.J.: The natural history of adult Crohn's disease in population-based cohorts. Am. J. Gastroenterol. 2010, 105(2), 289-297.

[11] Baumgart D.C., Sandborn W.J.: Inflammatory bowel disease: clinical aspects and established and envolving therapies. Lancet 2007, 369, 1641-1657.

[12] Margulies S., Kurian D., Elliott M.S., Han Z.: Vitamin D deficiency in patients with intestinal malabsorption syndromes - think in and outside the gut. J. Dig. Dis. 2015, 16(11), 617-633.

[13] Lashner B.A.: Red blood cell folate is associated with the development of dysplasia and cancer in ulcerative colitis. J. Cancer. Res. Clin. Oncol. 1993, 119, 549-554.

[14] Gasche C., Dejaco C., Waldhoer T., Tillinger W., Reinisch W., Fueger G.F., Gangl A., Lochs H.: Intravenous iron and erythropoietin for anemia associated with Crohn disease. A randomized, controlled trial. Ann. Intern. Med. 1997, 126, 782-787.

[15] Altomare R., Damiano G., Abruzzo A., Palumbo V.D., Tomasello G., Buscemi S., Lo Monte A.: Enteral nutrition support to treat malnutrition in inflammatory bowel disease. Nutrients 2015, 7, 2125-2133.

[16] Sohrabpour A.A., Malekzadeh R., Keshavarzian A.: Current therapeutic approaches in inflammatory bowel disease. Curr. Pharm. Des. 2010, 16(33), 3668-3683.

[17] Carter M.J., Lobo A.J., Travis S.P., IBD Section, British Society of Gastroenterology: Guidelines for the management of inflammatory bowel disease in adults. Gut 2004, 53(Suppl V), 1-16.

[18] Lochs H., Dejong C., Hammarqvist F.: ESPEN guidelines on enteral nutrition: gastroenterology. Clin Nutr. 2006, 25(2), 260-274.

[19] Triantafillidis J.K., Vagianos C.: The role of enteral nutrition in patients with inflammatory bowel disease: current aspects. BioMed Research International 2015 (Volume 2015), 1-12. 
[20] Bamba T., Shimoyama T., Sasaki M., Tsujikawa T., Fukuda Y., Koganei K., Hibi T., Iwao Y., Munakata A., Fukuda S., Matsumoto T., Oshitani N., Hiwatashi N., Oriuchi T., Kitahora T., Utsunomiya T., Saitoh Y., Suzuki Y., Nakajima M.: Dietary fat attenuates the benefits of an elemental diet in active Crohn's disease: a randomized, controlled trial. Eur. J. Gastroenterol. Hepatol. 2003, 15(2), 151-157.

[21] Walton M., Alaunyte I.: Do patients living with ulcerative colitis adhere to healthy eating guidelines? A cross-sectional study. Br. J. Nutr. 2014, 112(10), 1628-1635.

[22] Brasil Lopes M., Rocha R., Castro Lyra A., Rosa Oliveira V., Gomes Coqueiro F., Silveira Almeida N., Santos Valois S., Oliveira Santana G.: Restriction of dairy products; a reality in inflammatory bowel disease patients. Nutr. Hosp. 2014, 29(3), 575-581.

[23] Palant A., Koschack J., Rassmann S., Lucius-Hoene G., Karaus M., Himmel W.: And then you start to loose it because you think about Nutella: The significance of food for people with inflammatory bowel disease - a qualitative study. BMC Gastroenterol. 2015, 15(93), 1-11.

[24] Mansueto P., Seidita A., D’Alcamo A., Carroccio A.: Role of FODMAPs in patients with irritable bowel syndrome. Nutr. Clin. Pract. 2015, 30(5), 665-682.

[25] Halmos E.P., Power V.A., Shepherd S.J., Gibson P.R., Muir J.G.: A diet low in FODMAPs reduces symptoms of irritable bowel syndrome. Gastroenterology 2014, 146(1), 67-75.

[26] Shepherd S.J., Gibson P.R.: Fructose malabsorption and symptoms of irritable bowel syndrome: guidelines for effective dietary management. J. Am. Diet. Assoc. 2006, 106, 1631-1639.

[27] Marsh A., Eslick E.M., Eslick G.D.: Does a diet low in FODMAPs reduce symptoms associated with functional gastrointestinal disorders? A comprehensive systematic review and meta-analysis. Eur. J. Nutr. 2015 May 17. [Epub ahead of print].

[28] Böhn L., Störsrud S., Liljebo T., Collin L., Lindfors P., Törnblom H., Simrén M.: Diet low in FODMAPs reduces symptoms of irritable bowel syndrome as well as traditional dietary advice: a randomized controlled trial. Gastroenterology 2015, 149(6), 1399-1407.

[29] Cohen S.A., Gold B.D., Oliva S., Lewis J., Stallworth A., Koch B., Eshee L., Mason D.: Clinical and mucosal improvement with specific carbohydrate diet in pediatric Crohn disease. J. Pediatr. Gastroenterol. Nutr. 2014, 59(4), $516-521$.

[30] Khandalavala B.N., Nirmalraj M.C.: Resolution of severe ulcerative colitis with the specific carbohydrate diet. Case. Rep. Gastroenterol. 2015, 9(2), 291-295.

[31] Olendzki B.C., Silverstein T.D., Persuitte G.M., Ma Y., Baldwin K.R., Cave D.: An anti-inflammatory diet as treatment for inflammatory bowel disease: a case series report. Nutr. J. 2014, 13(5), 1-7.

[32] Boussenna A., Cholet J., Goncalves-Mendes N., Joubert-Zakeyh J., Fraisse D., Vasson M.P., Texier O., Felgines C.: Polyphenol-rich grape pomace extracts protect against dextran sulfate sodium-induced colitis in rats. J. Sci. Food. Agric. 2015, 96(4), 1260-1268.

[33] Ritchie L.E., Sturino J.M., Carroll R.J., Rooney L.W., Azcarate-Peril M.A., Turner N.D.: Polyphenol-rich sorghum brans alter colon microbiota and impact species diversity and species richness after multiple bouts of dextran sodium sulfate-induced colitis. FEMS Microbiol. Ecol. 2015, 91(3) [Epub ahead of print].

[34] Farzaei M.H., Rahimi R., Abdollahi M.: The role of dietary polyphenols in the management of inflammatory bowel disease. Curr. Pharm. Biotechnol. 2015, 16(3), 196-210.

[35] Costa C.A., Tanimoto A., Quaglio A.E., Di Stasi L.C.: Anti-inflammatory effects of Brazilian ginseng (Pfaffia paniculata) on TNBS-induced intestinal inflammation: Experimental evidence. Int. Immunopharmacol. 2015, 28(1), 459-469.

[36] Mascaraque C., González R., Suárez M.D., Zarzuelo A., Sánchez de Medina F., Martínez-Augustin O.: Intestinal anti-inflammatory activity of apigenin $\mathrm{K}$ in two rat colitis models induced by trinitrobenzenesulfonic acid and dextran sulphate sodium. Br. J. Nutr. 2015, 113(4), 618-626.

[37] Danese S., Fiocchi C.: Etiopathogenesis of inflammatory bowel diseases. World J. Gastroenterol. 2006, 12(30), 4807-4812.

[38] Kruis W., Schütz E., Fric P., Fixa B., Judmaier G., Stolte M.: Double-blind comparison of an oral Escherichia coli preparation and mesalazine in maintaining remission of ulcerative colitis. Aliment. Pharmacol. Ther. 1997, 11, 853-858.

[39] Anderson J.L., Hedin C.R., Benjamin J.L., Koutsoumpas A., Ng S., Hart A.L., Alastair Forbes A., Stagg A.J., Lindsay J.O., Whelan K.: Dietary intake of inulin-type fructans in active and inactive Crohn's disease and healthy controls: a case-control study. Crohns Colitis. 2015 Jul 27 [Epub ahead of print].

[40] Kuczyńska B., Wasilewska A., Biczysko M., Banasiewicz T., Drews M.: Krótkołańcuchowe kwasy tłuszczowe - mechanizmy działania, potencjalne zastosowania kliniczne oraz zalecenia dietetyczne. Now. Lek. 2011, 80, 4, 299-304.

[41] Banasiewicz T., Borycka-Kiciak K., Dobrowolska-Zachwieja A., Friediger J., Kiciak A., Krokowicz P., Małecka-Panas E., Pietrzak P., Rydzewska G., Tarnowski W., Zabielski R.: Kliniczne aspekty zastosowania kwasu masłowego $\mathrm{w}$ postępowaniu dietetycznym $\mathrm{w}$ chorobach jelit. Clinical aspects of sodium butyrate application in dietary treatment of bowel diseases. Przegl. Gastroenetrol. 2010, 5(6), 329-334.

[42] Kamińska B., Landowski P.: Rola wybranych czynników środowiskowych w etiopatogenezie nieswoistych zapaleń jelit. For. Med. Rodz. 2009, 3(1), 42-48.

[43] Lev-Tzion R., Griffiths A.M., Leder O., Turner D.: Omega 3 fatty acids (fish oil) for maintenance of remission in Crohn's disease. The Cochrane Libr. 2014 [Epub ahead of print]. 
[44] Massironi S., Rossi R.E., Cavalcoli F.A., Della Valle S., Fraquelli M., Conte D.: Nutritional deficiencies in inflammatory bowel disease: Therapeutic approaches. Clin. Nutr. 2013, 32, 904-910.

[45] Tyagi A., Kumar U., Santosh V.S., Reddy S., Mohammed S.B., Ibrahim A.: Partial replacement of dietary linoleic acid with long chain n-3 polyunsaturated fatty acids protects against dextran sulfate sodium-induced colitis in rats. Prostaglandins Leukot. Essent. Fatty Acids. 2014, 91(6), 289-297.

[46] Huang C.H., Hou Y.C., Yeh C.L., Yeh S.L.: A soybean and fish oil mixture with different n-6/n-3 PUFA ratios modulates the inflammatory reaction in mice with dextran sulfate sodium-induced acute colitis. Clin. Nutr. 2015, 34(5), 1018-1024.

[47] Liu B., Lin Q., Yang T., Zeng L., Shi L., Chen Y., Luo F.: Oat $\beta$-glucan ameliorates dextran sulfate sodium (DSS)-induced ulcerative colitis in mice. Food Funct. 2015, 6(11), 3454-3463.

[48] Martínez-Augustin O., Rivero-Gutiérrez B., Mascaraque C., Fermín Sánchez de Medina F.: Food derived bioactive peptides and intestinal barrier function. Int. J. Mol. Sci. 2014, 15(12), 22857-22873.

[49] Kozioł J., Gustaw W.: Kazeinomakropeptyd właściwości technologiczne i żywieniowe. Żywność-żywienie 2011, $65,34-36$.

[50] Sawin E.A., De Wolfe T.J., Aktas B., Stroup B.M., Murali S.G., Steele J.L., Ney D.M.: Glycomacropeptide is a prebiotic that reduces Desulfovibrio bacteria, increases fecal short chain fatty acids and is anti-inflammatory in mice. Am. J. Physiol. Gastrointest. Liver Physiol. 2015, 309(7), 590-601.

\author{
Adres do korespondencji: \\ Małgorzata Włochal \\ Szpital Kliniczny im. Heliodora Święcickiego \\ Uniwersytetu Medycznego w Poznaniu \\ ul. Przybyszewskiego 49 \\ 60-355 Poznań \\ tel./faks: 618691314 \\ e-mail: malgorzata_wlochal@o2.pl \\ Konflikt interesów: nie występuje \\ Praca wpłynęła do Redakcji: 27.10.2015 r. \\ Po recenzji: 19.11.2015 r. \\ Zaakceptowano do druku: 25.01.2016 r.
}

Received: 27.10.2015

Revised: 19.11.2015

Accepted: 25.01.2016 